\title{
The University Library Survey: Its Results
}

$\mathrm{T}$

HE UNIVERSITY library survey may be said to have come into rather frequent use in the I930's. It has recently been employed by the universities of South Carolina and Denver, and Stanford University, and it will doubtless continue to be employed as an effective means of improving the services of university libraries.

The nature, purpose, and general methodology of such surveys have been written about at length by $\mathrm{McDiarmid}^{1}$ and by Wilson and Tauber, ${ }^{2}$ and reviews of various individual surveys have appeared in library and educational journals. Consequently, this article will be concerned with only two types of the university library survey and will deal primarily with the results of surveys of individual institutions. Their purposes and the procedures followed in making them will be considered only as they are essential to an understanding of the results. The two types may be designated as limited and general.

Examples of both types may be cited. Five of the limited class will suffice for this category. Reports of two of these have been published: The University Libraries ${ }^{3}$ by Raney and A Faculty Survey of the University of Pennsylvania Libraries ${ }^{4}$ by the Bibliographical Planning Committee of

\footnotetext{
${ }^{1}$ MeDiarmid, E. W. The Library Survey. Chicago, American Library Association, 1940.

2 Wilson, Louis R., and Tauber, Maurice F. The University Library. Chicago, University of Chicago

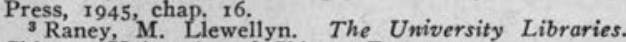
Chicago, University of Chicago Press, 1933.

4 Bibliographical Planning Committee of Philadelphia. A Faculty Survey of the University of Pennsylvania Libraries. Philadelphia, University of Pennsylvania Press, 1940.
}

Philadelphia. Three of the reports were not published. These were: "Report on the Proposed Program of Library Development in Support of Graduate Study at Atlanta University" by Louis R. Wilson, in 1943; "A Report on Certain Problems of the Libraries and School of Library Service of Columbia University" by Coney, Metcalf, and Wilson, and "Report of a Survey of the Technical Services of the Columbia University Libraries" by Tauber and Mumford, both in 1944 ; and a survey of the relation of the Department of Archives of Louisiana State University to the university library, in 1945, by Wilson and Crittenden.

Examples of general surveys include those of the universities of Georgia (in 1939, by Wilson, Branscomb, Dunbar, and Lyle); Florida (in 1940, by Wilson, Kuhlman, and Lyle) ; Mississippi (in 1940, by Kuhlman and Iben); Indiana (in 1940, by Coney, Henkle, and Purdy); and South Carolina (in 1946, by Wilson and Tauber).

The purposes of the limited surveys varied. The objective of the Chicago survey was to ascertain:

(I) The Faculty purposes, and (2) the library fitness to the attainment of those purposes. Accordingly, four leading questions were asked the staff of each department and school: (I) What is your goal? (2) What is the prime library equipment needed to reach that goal? (3) What is the present accoutrement? (4) What would be the cost, in arrears, and by the year? The answer to the first question might be abstract-in philosophic terms, or concrete-in terms of preferred research and teaching, or both. The 
answer to the second mainly involved source material. The third meant checking; the fourth, a budget.

In carrying out the Chicago survey two hundred members of the staff of the university were engaged in checking titles appearing in the Union List of Serials in Libraries in the United States and Canada for desiderata in designated subject fields for periodicals and in standard subject bibliographies for books. The findings, so far as the reading public was concerned, were published in the form of per cents of titles held and the amounts of money required to bring the collections up to the desired strength. The library and the departments, however, had the lists of desiderata to serve as a basis for purchase later, and both the library and the departments had undergone the valuable experience of studying together the library needs of the university on a university-wide basis.

The purpose of the Pennsylvania survey was different. It was expected that the survey would be of "value to the University itself as a guide in rounding out its collections and that it would likewise be of value to other librarians in the metropolitan area as a check-list upon existing resources." It was also intended as a first step in the general program of planning engaged in by the Bibliographical Planning Committee of Philadelphia in the development of bibliographical apparatus and the increase of library resources. In this respect it was of interest not only to the members of the faculty of the University of Pennsylvania but to the clienteles of all the libraries in and around Philadelphia.

The different subject fields were assigned to members of the instructional staff of the university and emphasis was placed upon (I) listing the major holdings by categories such as bibliographies, journals, histories, etc., in each field and (2) indicating the strength or weakness of the collections. Frequent reference was made to other collections in libraries in Philadelphia or the surrounding area. Members of the library staff prepared the articles dealing with the collections of reference works and bibliographies.

\section{The Columbia Survey}

At Columbia University the director of libraries had recently entered upon his duties as director and as dean of the school of library service. As he studied the administrative situations with which he was confronted, a number of questions arose concerning which he wished information and suggestion. The questions relating to the technical processes were submitted to two surveyors who dealt with them singly in advance of the more general aspects of the survey. Questions relating to government, organization, personnel, and accounting were assigned to one surveyor; those relating to the programs of the libraries and the school of library service, to another; and those concerning the future building program of the libraries, library budget and costs, exhibits; and library privileges, to another.

The surveyors spent ten days at the university, conferred with various members of the administrative staffs of the libraries, the school of library service, and the university, and with members of the instructional staff of the university who were interested in the services of the libraries and the program of instruction of the school. Reports were written separately by the surveyors, three of which, though prepared separately, were agreed upon by the authors and submitted as one report.

The purpose of the Atlanta University survey or conference related to the preparation of lists of publications essential to the development of a more extensive graduate 
program. To this end a committee of the faculty had studied the situation for a year, had prepared desiderata lists in a number of subject fields, and was at the point of seeking funds to carry the program into effect. The immediate purpose of the survey was to discuss the program with the graduate committee and librarian, offer suggestions concerning the lists, and aid the administration in the formulation and submission of a request for a grant.

\section{The Louisiana Survey}

The problem of Louisiana State University involved relationships between the growing department of archives of the university and the special collection of materials in the library relating to Louisiana and Louisiana history. The two collections were located in buildings some distance apart, and both were requiring additional space for their accommodation. The development of the archival collection also involved problems of support by the state and, if carried out as a thoroughgoing state department of archives, an extensive building program. There was also the problem of making clear the distinction between historical and archival materials and the responsibilities of the state and the university for the preservation and use of them.

The purposes of the surveys of the state university libraries were general. The stated purposes for the Florida survey may serve, with modifications, for them all. They were:

(I) To set the Library in the perspective of the history of the University, state, and region; (2) to discover ways and means of enabling it to improve its organization and administration as a part of the general administration of the University; (3) to formulate a plan of library development designed to promote the effectiveness of the University's general program of instruction, research, and extension; and (4) to indicate means by which the library resources of the University may be more effectively related to and integrated with the libraries of Florida, of the Southeast, and the nation.

In several of the surveys the development of departments of library science, particularly for the training of school librarians, was also included as a specific objective.

The procedures followed in carrying out the general surveys varied, but, again, those employed at Florida are typical. The survey was authorized by the institution. In the case of the surveys of Georgia, Florida, and Indiana, the survey was carried out by surveyors employed by the A.L.A. In the case of the surveys of Mississippi and South Carolina, they were made by surveyors employed directly by the universities.

\section{Method of Procedure}

Prior to their appearance on the campus, the surveyors acquainted themselves with the publications of the university, the annual reports of the librarian, and the university's general objectives. Upon arrival, they conferred with the administration and the librarian and then met with various committees, such as the library committee, and the deans of the various schools and colleges, and held interviews with the administrative officers, heads of schools and departments, business officers, heads of departments of the library and departmental libraries, and representative groups of students. Where the situation required it, they made visits to units of the university in other parts of the state or to other institutions and libraries in the state that might be interested in cooperative undertakings for the provision of bibliographical apparatus or resources for research. Usually, upon the conclusion of such activities, which required from seven to fourteen days, the surveyors summarized their general findings, made an oral report to the administration, and 
then returned to their homes to write up the reports. Usually a final conference was held, the report was put in final form, and, if the survey was made under the auspices of the A.L.A., the manuscript was turned over to it for mimeographing. If carried out under other auspices, other methods of publication were followed.

Information about the results of these surveys, either of the limited or general type, has not been generally available. The reasons for this are obvious. Some of the proposals or recommendations growing out of the surveys have related to long-time development, and sufficient time has not elapsed for them to be carried into effect. The survey of the University of South Carolina Library is only a year old, but already some of the recommendations have been put into effect. In some surveys, recommendations, particularly those relating to the centralization of administration or the clarification of administrative relationships, have met with opposition within the institutions or have been subjected to the delays incident to university administrative procedures. Still others have not been fully carried out due to the impact of the war upon appropriating bodies and universities and to other reasons.

But results have followed the surveys of both types, and they may now be presented in two general categories: (I) those growing out of the limited surveys and (2) those more or less common to all of the ten institutions. The results of the limited surveys are presented first. Those of the general surveys of the five state university libraries follow and are summarized in the table, which is based on information contained in a questionnaire submitted to the libraries and in letters from the librarians.

Results of the Limited Surveys

Atlanta University. Atlanta University prepared its desiderata lists, submitted a request for a grant to a foundation, and received twenty thousand dollars over a period of five years.

University of Chicago. A documents and foreign newspaper program was inaugurated for which a grant of one hundred thousand dollars was secured. The lists prepared by the departments have formed the basis for purchases since 1933 .

Columbia University. . The administrative organization of the libraries and the school of library service have been changed by the provision of assistant directors in charge of major divisions of the libraries and the appointment of an associate dean of the school of library service. A longterm program for the libraries is being developed and a number of the specific recommendations concerning administrative procedures and technical processes, etc., are being put into effect. The program of the school of library service is under consideration, particularly as it relates to the general graduate program of the university, and additions to the instructional staff are being made in the expectation that the graduate program of the school will be expanded.

Louisiana State University. It was recommended that the department of archives be made an integral part of the university library under the general administrative direction of the director of university libraries and that the university undertake to secure the development of a state department of archives financed by state funds and not out of the regular funds of the university. While the recommendations have not been carried out, the principle has been accepted by the administration, the library, and the department of archives, and the department "is in better position to contribute significantly to research in the University and the region" than it was when the survey was made. 


\section{Results of the General Surveys}

Seven results may be said to be common to the general surveys and, to a less extent, to the limited surveys also. In both instances it may not be correct to attribute the results entirely to the effect of the surveys since libraries, like other human institutions, are subject to many influences. The surveys, however, have been characterized as probably having exerted the greatest single influence in effecting the results.

I. First of all during the course of a survey the attention of the administrative officers and many members of the faculties is centered upon many aspects of library administration and service. This in itself can be set down as a distinct gain, since thinking about the library is indulged in far too infrequently by many of those in university administrations upon whom the support and direction of the library depends. Furthermore, this thinking is informed, due to the participation of persons who are experienced in various aspects of library and university administration and who bring to the consideration of the problems a detached, objective point of view. Opportunity is provided through meetings with administrative and business officers, deans, committees, heads of departments, and individualsthirty to fifty in all-to discuss the library program of the institution and to open the channels of communication for the transmission of ideas about the library between administration, library, and faculty that surveyors frequently find all but closed.

2. The second result is the education of the administration concerning the role of the library in the teaching and research programs of the university. The saying has long been current that it takes a university president at least five years to gain this understanding. If he has not already gained it, the final conference with the surveyors, supported later by the typed or mimeographed report, gives impetus to the process.

3. A third result sometimes takes the form of the codification of a library policy for the university that defines the relation of the librarian to the administration; makes clear what constitutes the library resources of the university; places the administration of these resources under the librarian; sets forth the duties of the librarian; provides for a library committee; and calls for the placing of the librarian and other qualified members, of the library staff upon those boards or committees that enable the library not only to keep informed concerning the administrative and educational programs of the university but to assist the university in their formulation.

4. A fourth result follows close after the third. Not only is a policy for the library set forth but a program of action for the library is developed. This can include administrative organization, financial support, personnel, technical operations, public services, library use, holdings, cooperative relationships with other libraries, etc., all of which have a place in a long-term program of library development.

5. To underwrite the library programs growing out of the surveys, greater financial support has been obtained. This has come principally from two sources: the state legislatures and educational foundations. Increased appropriations from the legislatures have been secured for personnel and books. The funds secured from educational foundations have been used for the purchase of special collections, for the employment of personnel for the inauguration of programs of training, and for the development of bibliographical apparatus.

6. Again, the survey may result in the solution of specific problems in any of the areas which keep the library from maintaining its services at a high level. 
Information Concerning Results of Surveys of University Libraries

Institutions

Fla. Ga. Ind. Miss. S.C.

I. Has the survey increased understanding by the university administration and faculty of what constitutes a proper program of library service in a university.

2. Has it resulted in the clarification of:

(a) The policy or government of the library.......

(b) The administrative organization of the library in relation to:

(I) The university administration............

(2) The departments and services of the library.

(3) Departmental and school libraries..........

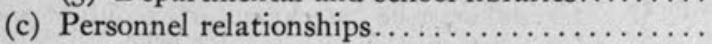

(d) Classification and pay plans ...............

(e) Academic status, tenure, sabbatical leave, retirement provisions, etc. ..................

3. Has it increased financial support for:

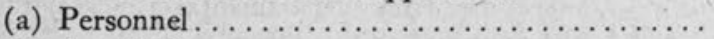

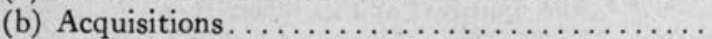

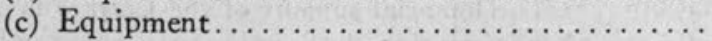

4. Has it resulted in improving the use of the library by:

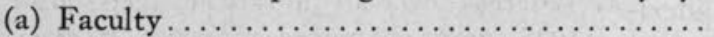

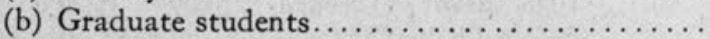

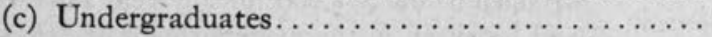

Yes Yes Yes Yes, Yes

Yes Yes Yes No Yes

Yes Yes $-{ }^{4}$ No Yes

Yes Yes ${ }^{4}$ No Yes

No Yes Yes No Yes

Yes Yes No No Yes

Yes Yes No No -9

No Yes No $\rightarrow-6 \quad-9$

Yes Yes ${ }^{5}$ Yes Yes

$\begin{array}{lllll}-1 & -1 & -5 & \text { Yes } & \text { Yes }\end{array}$

Yes Yes $\rightarrow$ Yes Yes

Yes Yes Yes -7 No

Yes Yes Yes $\rightarrow-7 \quad-7$

Yes Yes Yes $\rightarrow 7 \quad-7$

5. Has it affected the library program for:

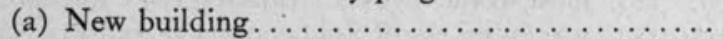

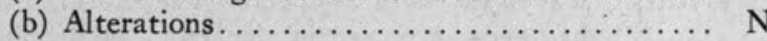

$\vec{F}^{2} \quad \overrightarrow{\mathrm{N}}^{2} \quad \overline{\mathrm{Y}}^{2} \quad \overrightarrow{\mathrm{Y}}^{2} \quad \mathrm{No}$

No No Yes Yes No

6. Has it affected training in library science:

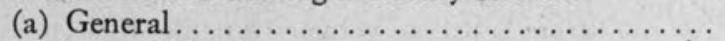

No

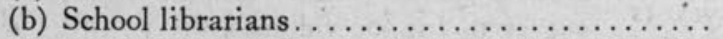

7. Has it resulted in the integration of the library through the librarian and other members of the library staff in the educational and research program of:

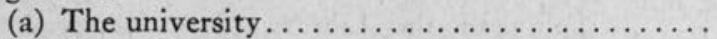

(b) Other libraries in the state...................

(c) Other libraries in the region...............

Yes

No

$\begin{array}{llll}\text { Yes } & \text { Yes } & \text { Yes } & -11 \\ \text { Yes } & \text { No } & \text { No } & -11 \\ \text { Yes } & \text { No } & \text { No } & -11\end{array}$

1 In addition to university funds a grant was received from the General Education Board.

2 Florida and Georgia have funds in hand for new buildings. Mississippi is working for a new building. "Sympathy for new building has been increased at Indiana." The South Carolina building is new.

3 Plans for training school librarians were held up by the war.

" "Did not require clarification."

" "Over-all support has been increased, largely because president became interested in library for various reasons."

- Library staff is included in state retirement plan. No other provisions.

7 Use has increased. Cause for increase not determined.

8 Cannot say. Library has received a grant for training school librarians.

- Classification and pay plans and academic status are under consideration. Tenure, retirement provisions, etc., are vai lable to library staff members with professional rank.

10 "Will make the re-establishment of library science courses easier."

11 "Not yet. Eventually its influence will be felt on these points."

Sources: Answers to a questionnaire, letters from the librarians of the respective universities, and Barmore, Nelle. "A Report on A Survey of the University of Florida Library, by Wilson-Kuhlman-Lyle." Gainesville, 1946. 16p. 
7. A final by-product of the surveys is the stimulation of the library staff. There are many college and university libraries whose staffs suffer isolation from the teaching and research activities of the institution with which they work. They concern themselves with the everyday routine of library management. The survey, if properly conceived, focuses attention upon the objectives of the university. It places the library in the current of institutional thinking and consćiously points out through suggestions and recommendations to the administrative officers and members of the faculty the part that library staff members may play in achieving the aims of the university. The effect is tonic and leads to more efficient library service. Furthermore, the effect may extend beyond the boundaries of the campus. The survey is read by other librarians in the state, region, and nation. It becomes a part of the professional literature that sets standards and holds up ideals for librarianship generally.

The survey of the University of Georgia Library is the oldest of the general surveys of the state university libraries. Seven years have elapsed since it was made. Conse'quently, there has been sufficient, time for the recommendations made by the surveyors to be carried into effect. Although the results of all five of the state university surveys are summarized in the table, the nature of the measures taken by the universities is worthy of note. Ralph Halstead Parker, director of libraries of the University of Georgia, has indicated in the following excerpts from a letter of July 2, 1946, what their nature has been:

After the lapse of more than seven years since the survey, most of the work of reorganizing the Library Staff has been completed and the direction of the remainder of the reorganization has already been charted. At the time this stage of development arrived, I went back to the survey and checked the recommendations against the accomplishments and definite program in progress. It was interesting to find that every recommendation has been carried out except that regarding the development of Library Science training. In most cases, we have exceeded the recommendations of the survey committee in matters of salary, staff, book budget, and the like.

In 1940, a new set of Statutes of the University were adopted by the Regents, in which the government and administrative relations of the Library were clearly set out. These Statutes provide for all items which were recommended by the survey committee. They provide for a centralized administration of all Libraries by the Director of Libraries and provide that no books or other graphic materials may be purchased or acquired independently of the Director of Libraries. As a matter of administrative interpretation, the Comptroller will not approve recommendations for the purchase of even dictionaries for office use from departmental funds without the approval of this office.

The financial support of the Library by the Administration has improved considerably. Whereas over-all library budgets prior to 1938 never exceeded $\$ 40,000$, it has not dropped below $\$ 75,000$ for any year since 1940 and has been in the neighborhood of $\$ 100,000$ most of these years. In 1945-1946, the budget was in excess of $\$ 134,000$. The Library Staff has been increased in size from 14 members to 32 members. Holdings have increased from 136,000 volumes at the time of the survey to 205,000 volumes.

The Statutes of 1940 provide that upon the recommendation of the Director of Libraries members of the Library Staff may be given appropriate academic rank. It has been the policy of the Library to accord academic status to those members of the Library Staff whose educational qualifications were such as to merit their admittance into the University Faculty. Positions in the Library have been classified according to their relative faculty position so that the Library Staff is integrated into the classification and pay plan of the University $/$ Faculty. Professional members of the Library Staff have the same tenure as that accorded members of the Faculty and participate in the University Retirement Program. Sabbatical leave is not granted to anyone in the University. 
The Library has been an active participant in interlibrary affairs in Georgia, particularly in the development of the regional Union Catalog and the cooperative library program of the University Center of Atlanta. The Director of Libraries has been a member of the Library Committee of the University System of Georgia which during the war, however, has practically ceased to function.

The Director of Libraries is a member of the Executive Committee of the Graduate Faculty. The inclusion of the Director in this Committee may or may not be the result of the library survey.

The great upheaval of the war and the present readjustments which are following the return to peace make it hard to evaluate any changes in the use of the Library. We have observed a considerable increase in library use by the student body and a certain increase by the Faculty. The total use of the Library, however, is not yet satisfactory. There is a far better attitude on the part of the library public toward the Library and the library program than existed in 1940; and as soon as it is possible for the University Faculty and student body to stabilize, the library use will doubtless improve.

We are in the process of preparing plans for a new library building which is to be constructed as soon as conditions permit. There have been no improvements in existing facilities and will probably be none, in view of the

\section{Scientific Periodicals}

\section{(Continued from page 359)}

a study of the Agricultural Index made by Orr. ${ }^{8}$ Of the forty-seven most quoted periodicals, only five were from the pure science field, a percentage far below that shown above. A similar study by Pohle ${ }^{9}$ of material included in the Experiment Station Record shows a similar trend. That abstracting and indexing services should remain close to their indicated fields seems entirely justifiable, however, for the large

8 Orr, Robert W. "Preliminary Survey of the Agricultural Index as a Bibliographic Service for Land-grant College and University Libraries." Master's thesis. Columbia University, r939.

Pohle, G. A. "Study of the Agricultural Index and Experiment Station Record, June 1936 to July 1937." Thesis. University of Michigan, I940. prospects for the new library building. This building is not the result of the library survey.

Training in Library Science has not been developed, largely because of the disruption from the war. It is part of the Library's plans to establish an adequate program for the training of school librarians and teacherlibrarians and for training persons for junior positions in the public libraries in the State.

The results of all the five surveys have not been so extensive or so substantial as those set forth by Dr. Parker. But they are substantial. The criticism could also be made that the surveys are very much alike in form and scope, that they are elementary, that when one is read there is little need to read the others. Such criticism is easy to make but is wide of the mark. They have been somewhat alike because they represent prescriptions for libraries, for different libraries, however, and they are directed at specific as well as general ends. They are elementary because they have been intended for administrative officers and faculty members who are not experts in library administration but whose sympathetic understanding and cooperation are essential to the carrying out of an effective, significant library program.

amount of duplication already existing would be greatly increased should they attempt to cover all important related fields.

This study leads to the conclusion that librarians as well as makers of the professional college curriculum are entirely justified in stressing the importance of the pure sciences. It is clearly shown that the importance of periodicals in the individual sciences and of such general publications as scientific society proceedings cannot be judged on the basis of their value to one or two subjects but must be selected on the basis of their value to all of the related fields of research, both pure and applied. 